\title{
Hafif-Orta Düzeyde Hiperkolesterolemili Bireylerde Bitkisel Stanol İçeren Yoğurt Tüketiminin Oksidatif Stres Üzerine Etkisi
}

\author{
The Effects of Plant Stanol Ester Containing Yoghurt on Oxidative Stress in Mild-Moderate \\ Hypercholesterolemic Individuals
}

\author{
Mehmet Fisunoğlư ${ }^{1}$ Burcu Aksoy Canyolu², Zehra Büyüktuncer Demirel ${ }^{3}$, Gülay Sain Güven ${ }^{4}$, \\ Serhat Ünal ${ }^{5}$ H. Tanju Besler ${ }^{6}$
}

Geliş tarihi/Received: 24.10.2018 • Kabul tarihi/Accepted: 30.11.2018

\section{ÖZET}

Amaç: Bu çalışmanın amacı, kolesterol düşürücü özelliği olduğu bilinen bitkisel stanol esteri alımı sonucu gerçekleşen serum kolesterol düzeylerindeki düşüşün, antioksidan kapasite ve bazı oksidatif stres göstergeleri üzerindeki etkisini incelemektir.

Bireyler ve Yöntem: Çalışma, bitkisel stanol esteri içeren yoğurt tüketimine bağlı olarak serum LDL kolesterol düzeyinde önemli düzeyde azalma gerçekleşen 8 hiperkolesterolemi hastası ile plasebo kontrol yoğurdu tüketen ve serum LDL kolesterol düzeyinde değişim gerçekleşmeyen 8 hiperkolesterolemi hastası üzerinde yürütülmüştür. Çalışma süresince çalışmaya katılan kişilerin yaşam tarzlarında veya beslenme düzenlerinde bir değişiklik yapmamaları istenmiştir. Çalışmada bireylerin serum lipit düzeylerine ek olarak, araştırma yoğurtlarının tüketiminin öncesinde ve 4 hafta sonundaki serum total antioksidan kapasite, okside LDL ve 8-prostaglandin $F_{2 a}$ düzeyleri karşılaştırılmıştır.

Bulgular: Çalışma sonunda bitkisel stanol esteri içeren yoğurt tüketen kişilerin serum total kolesterol, LDL kolesterol düzeylerinde önemli düzeyde azalma gerçekleşmiştir. Öte yandan bu azalmanın, kişilerin antioksidan kapasite ve oksidatif stres düzeylerine aynı miktarda yansımadığı belirlenmiştir.

Sonuç: Hafif-orta düzeyde hiperkolesterolemisi olan kişilerin 4 hafta süresince bitkisel stanol tüketmelerinin serum total kolesterol ve LDL kolesterol düzeylerini azalttığı, ancak bu azalmanın serum oksidatif stres göstergeleri üzerine istatistiksel açıdan önemli bir etkisinin olmadığı sonucuna varılmıştır.

Anahtar kelimeler: Bitkisel stanol esteri, antiloksidan kapasite, oksidatif stres, kolesterol

\footnotetext{
ABSTRACT

Aim: The main aim of the current study was to examine the effects of plant stanol esters, which are well known with their cholesterol lowering effects, on antioxidant capacity and certain oxidative stress markers.

Subjects and Method: This study was conducted on 8 hypercholesterolemia patients whose serum LDL cholesterol

1. İletişim/Correspondence: Hacettepe Üniversitesi Sağllk Bilimleri Fakültesi Beslenme ve Diyetetik Bölümü, Ankara, Türkiye

E-posta: evrims1979@yahoo.com • 난 https://orcid.org/0000-0002-0021-7811

2. Hacettepe Üniversitesi Sağlık Bilimleri Fakültesi Beslenme ve Diyetetik Bölümü, Ankara, Türkiye • 이 https://orcid.org/0000-0003-0205-4099

3. Hacettepe Üniversitesi Sağlık Bilimleri Fakültesi Beslenme ve Diyetetik Bölümü, Ankara, Türkiye - (1) https://orcid.org/0000-0002-2039-8568

4. Hacettepe Üniversitesi Tıp Fakültesi İç Hastalıkları Anabilim Dalı, Ankara, Türkiye (1) https://orcid.org/0000-0001-8176-9767

5. Hacettepe Üniversitesi Tıp Fakültesi İnfeksiyon Hastalıkları ve Klinik Mikrobiyoloji Anabilim Dall, Ankara, Türkiye • ำ https://orcid.org/0000-0003-1184-4711

6. Doğu Akdeniz Üniversitesi Sağlık Bilimleri Fakültesi Beslenme ve Diyetetik Bölümü, Gazimağusa, KKTC • (1) https://orcid.org/0000-0002-6523-7995
} 
level was significantly decreased after plant stanol ester containing yoghurt consumption for 4 weeks and another 8 hypercholesterolemia patients whose LDL cholesterol levels stayed stable after consumption of placebo yoghurts. During the study the patients were requested not to change their lifestyles and dietary habits. In addition to serum lipid levels, serum total antioxidant capacity, oxidized LDL and 8 prostoglandin $F_{2 a}$ levels of the patients were compared before and 4 weeks after the intervention period.

Results: As a result of the study, serum total and LDL cholesterol levels were significantly decreased in patients who consumed plant stanol ester containing yoghurt for 4 weeks. However, the decrease in serum lipid levels did not reflect to antioxidant capacity and oxidative stress biomarkers.

Conclusion: It has been determined that consumption of plant stanol ester containing yoghurt in patients with mild to moderate hypercholesterolemia for 4 weeks have lowered serum total and LDL cholesterol levels but this decrease does not have a statistically significant effect on serum antioxidant capacity and oxidative stress biomarkers.

Keywords: Plant stanol ester, antioxidant capacity, oxidative stress, cholesterol

\section{GíRIŞ}

Epidemiyolojik ve klinik araştırmalar bitkisel sterol ve stanol içeren ürünleri tüketmenin kardiyovasküler yararlarını göstermiştir (1-3). Klinik yararları bilimsel kılavuzlarca da belirtilen bitkisel sterol ve stanollerin kolesterol metabolizmasındaki etkilerinin altında yatan yolaklar hala tam olarak açıklanamamaktadır. Yapısal olarak, kolesterol ile bitkisel sterol ve stanoller arasında büyük benzerlik olmakla birlikte, diyet kolesterolüne kıyasla oldukça az emilen bitkisel sterol ve stanollerin, bağırsak lümeninde kolesterol ile emilim için yarıştığı, enterosit ve hepatositlerde kolesterol metabolizması ile ilişkili genlerin transkripsiyonunu indüklediği bilinmektedir (4-6).

Serum total kolesterolü, özellikle düşük yoğunluklu serum kolesterol (LDL) düzeyi ve oksidatif stres, kardiyovasküler hastalıkların (KVH) gelişimindeki önemli risk etmenleridir. Aynı şekilde lipit peroksidasyonu sonucu oluşan ürünler ve yapışkan moleküller gerek aterosklerotik plaklarda yer almakta gerekse düşük dereceli inflamasyona neden olarak, aterosklerozun gelişiminde ve ilerlemesinde önemli rol oynamaktadır (7). Serum yapışkan molekül düzeyindeki artışa ek olarak, C reaktif protein (CRP) gibi düşük dereceli inflamasyon göstergelerindeki artışların KVH riskleri ile ilişkili olabileceği düşünülmektedir (8). Dolayısiyla in vivo olarak oksidatif stresi ve serum kolesterol düzeyini azaltan stratejiler "kardiyokoruyucu” etkili olarak kabul edilmektedir $(9,10)$.
Kardiyovasküler yararları oldukça iyi bilinen bitkisel sterol ve stanol alımının, plazma yağda çözünen vitaminler ve beta karoten başta olmak üzere karotenoid düzeylerini etkileyebileceği, ancak bu değişimlerin serum A vitamini düzeyini önemli ölçüde etkilemeyeceği yönünde çalışmalar bulunmaktadır $(11,12)$. Teorik olarak, bitkisel sterol/stanol ve bunların esterlerinin alımına bağlı olarak karotenoid düzeylerindeki azalma, diğer serum antioksidan enzimlerindeki artışlar ile telafi edilebilmektedir (13). Bunlara ek olarak, serum kolesterol düzeyindeki azalmanın aterosklerotik plak oluşumunu önlemesinin ötesinde, serum antioksidan kapasiteyi arttırdığını gösteren gerek in vitro, gerekse in vivo çalışmalar mevcuttur (14-16). Ancak, bu çalışmaların büyük bir çoğunluğunda ilaç kaynaklı kolesterol düşürme stratejilerinin etkinliği araştırılmıştır. İlaç tedavisinden bağımsız, sadece bitkisel sterol ve stanol alımına bağlı serum antioksidan durum ve oksidatif stres göstergeleri üzerindeki etkinliğini inceleyen araştırma sayısı oldukça kısıtlıdır (11-13).

$\mathrm{Bu}$ çalışmaya öncülük eden araştrrmada günde $1.9 \mathrm{~g}$ düzeyinde bitkisel stanol esteri alımının hafiforta düzeyde hiperlipidemisi bulunan bireylerde kan yağlarını ve lipoproteinlerini olumlu şekilde etkilediğini gösterilmiştir (9). $\mathrm{Bu}$ araştırma ise bu bireylerde bitkisel stanol alımına bağlı gerçekleşen serum lipit ve lipoprotein sevilerindeki değişimlerin, 
serum antioksidan düzeyi ve oksidatif stres göstergeleri üzerindeki etkilerini belirlemek amacı ile yapılmıştır.

\section{BİREYLER VE YÖNTEM}

\section{Örneklem Seçimi ve Araştırma Planı}

$\mathrm{Bu}$ çalışma daha önce yaptığımız araştırma içinden seçilen bir alt grup içinde yapılmıştır. Bir önceki araştırmada yeni hiperkolesterolemi tanısı almış yetişkinlerden 4 hafta süresince yaşam tarzı ve beslenme alışkanlıklarında bir değişiklik yapmadan her gün $1.9 \mathrm{~g}$ bitkisel stanol esteri içeren yoğurdu (PSta) tüketmeleri istenmişti. Bu çalışmada, bir önceki araştırmada serum LDL kolesterol düzeyinde en fazla düşüş yaşanan 8 kişi ile bir önceki araştırmada kontrol grubunda (Kntr) yer alan ve 4 hafta süresince bitkisel stanol esteri içermeyen ancak görüntü, tat ve kıvam olarak aynı özelliklerdeki plasebo yoğurdu düzenli olarak tüketen ve serum LDL kolesterol düzeylerinde bir değişiklik olmayan 8 kişinin serum örnekleri üzerinde gerçekleştirilmiştir. Daha önce yapılan araştırma süresince bireylerin çalışma başı ve sonunda bel-kalça çevreleri, vücut ağırlığı ölçümleri (Tanita BC-418) ve toplam vücut bileşimi analizleri (Tanita BC-418) ile bir günü hafta sonuna gelen "3 günlük besin tüketim kayıtları" alınarak besin tüketimleri değerlendirilmiştir (9).

\section{Serum Örneklerinin Toplanması ve Analizleri}

Çalışmada kullanılan serum örnekleri Hacettepe Üniversitesi Tip Fakültesi Hastanesi Dâhiliye Polikliniği hemşireleri tarafından 12 saatlik açlık sonunda alınmış ve 2 saat içinde Hacettepe Üniversitesi Beslenme ve Diyetetik Bölümü Araştırma Laboratuvarında serumlarına ayrılarak, analiz edilinceye kadar $-80^{\circ} \mathrm{C}$ 'de saklanmıştır. Serum lipit, lipoprotein ve CRP düzeyleri Hacettepe Üniversitesi Tıp Fakültesi Hastanesi Biyokimya Laboratuvarında rutin analizlerle incelenmiş, serum total antioksidan kapasite (TAC) (Cayman Chemical, USA) ve oksidatif gösterge analizleri Beslenme ve Diyetetik Bölümü Araştırma Laboratuvarında kit yardımı ile belirlenmiştir. Buna göre total antioksidan kapasite, 8- isoprostan ve okside LDL (ox-LDL) düzeyleri kit talimatlarına göre analiz edilmiştir.

\section{Verilerin İstatistiksel Değerlendirmesi}

Verilerin istatistiksel değerlendirilmesi SPSS 21.0 paket programı yardımı ile yapılmıştır. Tanımlayıcı istatistikler, örneklem sayısı göz önüne alınarak ortanca, en az-en fazla olarak verilirken, tekrarlayan bağll ölçümlerin değerlendirilmesinde Wilcoxon testi, bağımsız örneklerin karşılaştırılmasında Mann-Whitney U testi kullanılmıştır. Sonuçlar \%95 güven aralığında, anlamlılık $\mathrm{p}<0.05$ düzeyinde değerlendirilmiştir. Eğri altı alan hesaplamalarında Microsoft Excel 2016 paket programı kullanılmıştır.

\section{BULGULAR}

Çalışmaya dahil edilen bireylerin serum total kolesterol düzeyleri 226-287 mg/dL arasındadır. PSta grubu, yaşları 36 ve 54 arası 4 erkek ve 4 kadından oluşurken, Kntr grubu 23-65 yaş arası 3 kadın ve 5 erkek bireyden oluşmaktadır. İki grubun beden kütle indeksleri (BKI) ortancalarının 29.7 ve 28.1 olduğu ve çalışma başında bunlar arasında bir fark olmadığı görülmektedir ( $p>0.05)$. Çalışma dahil edilen bireylerin özellikleri Tablo 1'de gösterilmiştir.

Tablo 1. Katılımcı özellikleri

\begin{tabular}{lcc}
\hline \multirow{2}{*}{ Özellikler } & PSta & Kntr \\
\cline { 2 - 3 } & $\begin{array}{c}\text { Ortanca } \\
\text { (En az-en fazla) }\end{array}$ & $\begin{array}{c}\text { Ortanca } \\
\text { (En az-en fazla) }\end{array}$ \\
\hline Kadın/erkek (n) & $4 / 4$ & $3 / 5$ \\
Yaş (yıl) & $47(36-54)$ & $44(23-65)$ \\
BKİ (kg/m²) & $29.7(25.2-34.0)$ & $28.1(22.4-33.2)$ \\
BMH (kkal/gün) & $1485.0(1314.0-1955.0)$ & $1386.0(1270.0-1711.0)$ \\
Bel/kalça oranı & $0.92(0.82-1.02)$ & $0.91(0.81-1.00)$ \\
\hline
\end{tabular}

PSta: Bitkisel stanol esteri içeren yoğurdu tüketen grup, Kntr: Kontrol grubu, BMH: Bazal metabolizma hızı, BKI: Beden kütle indeksi

Bireylerin çalışma başlangıcındaki ve sonundaki enerji ve makro besin ögesi alımları incelendiğinde iki grubun da enerji ve makro besin ögesi alımlarındaki değişimlerin istatistiksel olarak benzer olduğu belirlenmiştir ( $p>0.05)$. Ayrıca iki grubun da 
karbonhidrat alımlarının önerilerin altında (\%48.3, istenenlerden farklı olduğu görülmektedir. Bunlara \%44.4), yağ alımlarının önerilerin üzerinde (\%37.1, ek olarak, çalışma başında diyetle alınan kolesterol \%41.5) olduğu görülmektedir. Bu durumun çalışma düzeyleri her iki grup için de önerilerin üzerinde iken, sonunda da değişmediği Tablo 2'de görülmektedir. çalışma sonunda PSta grubunda diyetle kolesterol Diyet yağı alımlarının yüksekliğine ek olarak, her iki alımının azaldığı, ancak bu azalışın istatistiksel olarak gruptaki bireylerin diyet yağ asidi örüntülerinin de anlamlı düzeyde olmadığı görülmektedir ( $p>0.05)$.

Tablo 2. Çalışma süresince katılımcıların günlük enerji ve besin ögesi alımları

\begin{tabular}{|c|c|c|c|c|c|}
\hline \multirow[b]{2}{*}{ Enerji ve besin ögeleri } & PSta & Kntr & \multirow[b]{2}{*}{ p1 } & \multirow[b]{2}{*}{ p2 } & \multirow[b]{2}{*}{ p3 } \\
\hline & $\begin{array}{c}\text { Ortanca } \\
\text { (en az-en fazla) }\end{array}$ & $\begin{array}{c}\text { Ortanca } \\
\text { (en az-en fazla) }\end{array}$ & & & \\
\hline \multicolumn{6}{|l|}{ Enerji (kkal) } \\
\hline Çalışma başlangıcı & 1633 (1160-1977) & 1461 (931-2002) & & & \\
\hline Çalışma sonu & $1924(1363-2758)$ & $1944(1050-3058)$ & & & \\
\hline Değişim & $290.7(-528-1598)$ & $482.8(-224-1409)$ & 0.161 & 0.125 & 0.290 \\
\hline \multicolumn{6}{|l|}{ Yağ (\%) } \\
\hline Çalışma başlangıcı & $37.1(29.3-46.0)$ & $41.5(36.0-52.3)$ & & & \\
\hline Çalışma sonu & $33.6(27.7-43.0)$ & $39.1(30.7-49.5)$ & & & \\
\hline Değişim & $-3.5(-8.3-1.3)$ & $-2.4(-7.7-9.2)$ & 0.063 & 0.161 & 0.860 \\
\hline \multicolumn{6}{|l|}{ DYA (\%) } \\
\hline Çalışma başlangıcı & $12.8(10.4-17.3)$ & $12.8(8.9-15.0)$ & & & \\
\hline Çalışma sonu & $11.6(9.4-17.8)$ & $12.2(9.0-17.2)$ & & & \\
\hline Değişim & $-1.22(-4.7-3.8)$ & $-0.62(-6.0-3.6)$ & 0.674 & 0.069 & 0.529 \\
\hline \multicolumn{6}{|l|}{ TDYA (\%) } \\
\hline Çalışma başlangıcı & $13.6(7.8-17.5)$ & $14.5(10.4-23.6)$ & & & \\
\hline Çalışma sonu & $12.8(9.7-16.6)$ & $13.2(9.6-18.8)$ & & & \\
\hline Değişim & $-0.86(-5.4-3.0)$ & $-1.3(-8.1-2.8)$ & 0.575 & 0.208 & 0.753 \\
\hline \multicolumn{6}{|l|}{ ÇDYA (\%) } \\
\hline Çalışma başlangıcı & $8.4(5.33-14.4)$ & $11.6(7.4-17.2)$ & & & \\
\hline Çalışma sonu & $7.6(5.8-9.1)$ & $12.0(8.0-14.7)$ & & & \\
\hline Değişim & $-0.80(7.4-3.5)$ & $0.31(-3.6-3.6)$ & 0.889 & 0.123 & 0.459 \\
\hline \multicolumn{6}{|l|}{ Protein (\%) } \\
\hline Çalışma başlangıcı & $14.5(11.7-17.3)$ & $14.0(11.7-17.7)$ & & & \\
\hline Çalışma sonu & $14.2(11.3-16.7)$ & $14.8(10.0-18.0)$ & & & \\
\hline Değişim & $-0.38(-5.7-3.7)$ & $0.75(-2.7-5.0)$ & 0.778 & 0.624 & 0.630 \\
\hline \multicolumn{6}{|l|}{ CHO (\%) } \\
\hline Çalışma başlangıcı & $48.3(34.7-55.0)$ & $44.4(29.7-52.3)$ & & & \\
\hline Çalışma sonu & $52.3(45.0-61.3)$ & $45.9(33.5-55.3)$ & & & \\
\hline Değişim & $3.96(-3.3-8.7)$ & $1.56(-8.8-7.7)$ & 0.135 & 0.575 & 0.290 \\
\hline \multicolumn{6}{|l|}{ Kolesterol (mg) } \\
\hline Çalışma başlangıcı & $219.6(128.4-364.1)$ & 201.6 (159.6-391.7) & & & \\
\hline Çalışma sonu & $187.2(95.3-279.0)$ & $217.8(112.6-381.9)$ & & & \\
\hline Değişim & $-32.35(-139.4-27.1)$ & $16.2(-56.7-112.8)$ & 0.263 & 0.484 & 0.170 \\
\hline \multicolumn{6}{|c|}{$\begin{array}{l}\text { PSta: Bitkisel stanol esteri içeren yoğurdu tüketen grup, Kntr: Kontrol grubu, DYA: Doymuş ya } \\
\text { asidi, CHO: Karbonhidrat, \% Enerjiye olan yüzdesi } \\
\text { p1, PSta grubu için çalışma başlangıcı ve çalışma sonu Wilcoxon testi sonuçları } \\
\text { p2, Kntr grubu için çalş̧ma başlangıcı ve çalışma sonu Wilcoxon testi sonuçları } \\
\text { p3, PSta ve Kntr gruplarının değişimlerin Mann-Whitney U testi sonuçları }\end{array}$} \\
\hline
\end{tabular}


Tablo 3'te bitkisel stanol esterleri alımlarının kan yağları üzerindeki etkisi gösterilmiştir. Buna göre PSta grubunun serum total kolesterol, LDL kolesterol ve Apo B düzeyleri gerek çalışma öncesine göre, gerekse çalışma sonu Kntr grubuna göre istatistiksel olarak anlamlı düzeyde azalmıştır. Her iki grubun da serum HDL kolesterol düzeylerinde önemli bir değişiklik olmamıştır ( $p>0.05)$. Ayrıca bitkisel stanol esterli yoğurt tüketen gruptaki serum total kolesterol/ HDL kolesterol oranın çalışma başlangıcına göre istatistiksel olarak önemli düzeyde azaldığı görülmektedir.

Tablo 3. Bitki stanol esterinin çalı̧̧ma süresince serum lipit ve lipoprotein düzeylerine etkisi

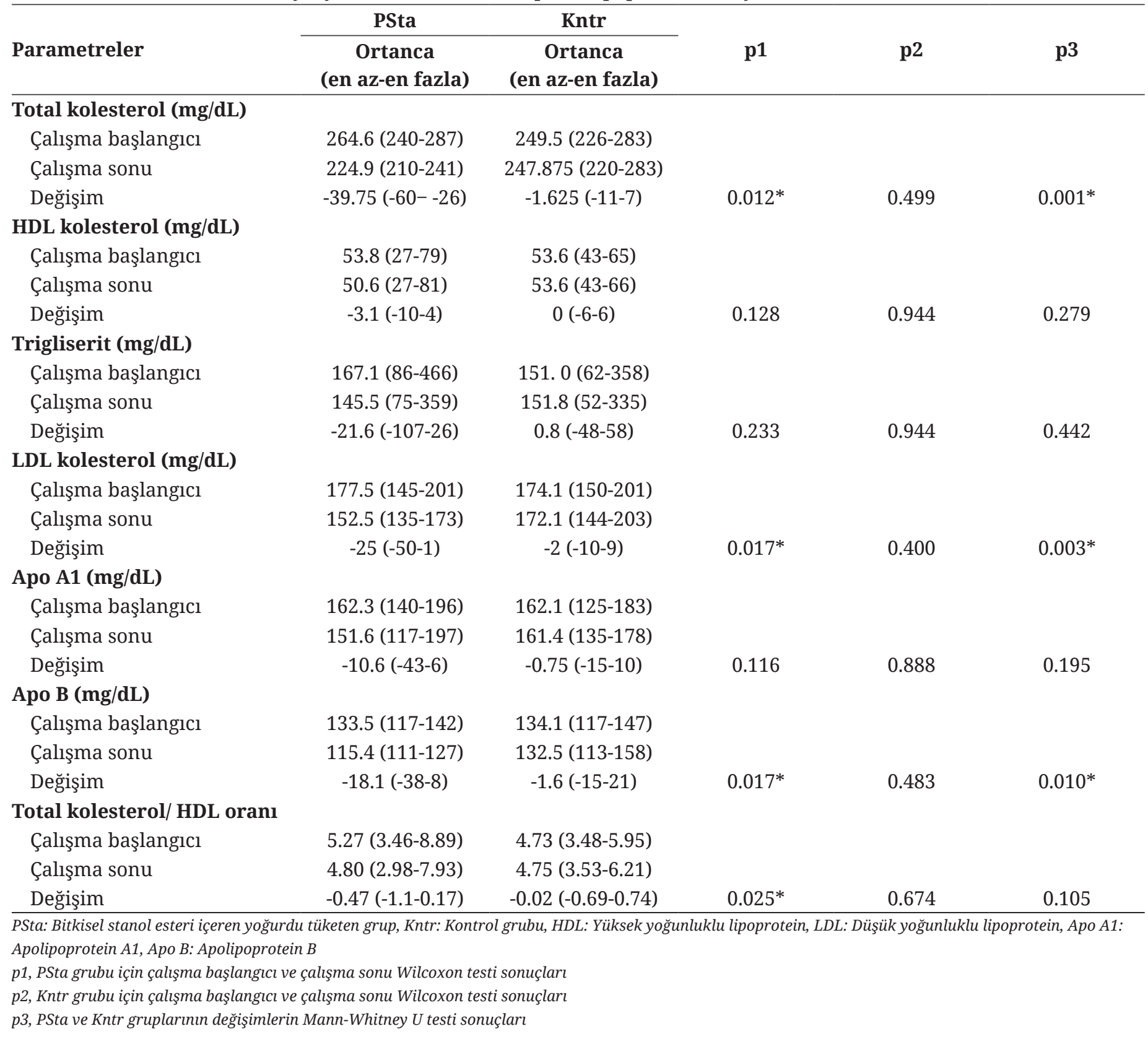

Tablo 4'te serum LDL kolesterol ve total kolesterol düzeylerindeki azalmanın serum antioksidan kapasite ve oksidatif göstergelerde yaptığı değişiklik gösterilmiştir. Buna göre çalışma sonunda PSta grubundaki bireylerin total antioksidan kapasitelerinde istatistiksel düzeyde anlamlı 
olmayan, ancak hafif bir artsş olduğu görülmektedir ( $>0.05$ ). Bununla beraber bu kişilerin oksidatif stres göstergelerinde de istatistiksel olarak anlamlı olmayan, hafif azalmalar söz konusudur ( $\mathrm{p}>0.05$ ). Benzer azalmalar Kntr grubunda da gerçekleştiği için gruplar arasinda istatistiksel olarak anlamlı bir fark bulunmamıştır ( $\mathrm{p}>0.05$ ).

Tablo 4. Bitkisel stanol kullanımının çalışma süresince serum antioksidan kapasite ve oksidatif stres göstergelerine etkisi

\begin{tabular}{|c|c|c|c|c|c|}
\hline \multirow{2}{*}{$\begin{array}{l}\text { Antioksidan kapasite ve } \\
\text { oksidatif stres göstergeleri }\end{array}$} & PSta & Kntr & \multirow[b]{2}{*}{ p1 } & \multirow[b]{2}{*}{ p2 } & \multirow[b]{2}{*}{ p3 } \\
\hline & $\begin{array}{c}\text { Ortanca } \\
\text { (en az-en fazla) }\end{array}$ & $\begin{array}{c}\text { Ortanca } \\
\text { (en az-en fazla) }\end{array}$ & & & \\
\hline \multicolumn{6}{|l|}{ TAC $(\mu \mathrm{mol} / \mathrm{L})$} \\
\hline Çalışma başlangıcı & $340.2(309.1-364.2)$ & 316.87 (241.75-375.84) & & & \\
\hline Çalışma sonu & $338.2(300.5-363.0)$ & 300.29 (123.25-433.32) & & & \\
\hline Değişim & $-2.1(-14.11-12.98)$ & $-16.58(-140.84-72.89)$ & 0.575 & 0.674 & 0.529 \\
\hline \multicolumn{6}{|l|}{ Ox-LDL (pg/dL) } \\
\hline Çalışma başlangıcı & $66.0(32.56-95.21)$ & $54.95(32.00-67.40)$ & & & \\
\hline Çalışma sonu & $54.9(27.1-74.1)$ & $46.30(32.46-65.42)$ & & & \\
\hline Değişim & $-11.1(-30.09-8.54)$ & $-8.66(-23.21-5.64)$ & 0.069 & 0.069 & 0.674 \\
\hline \multicolumn{6}{|l|}{ 8-prostaglandin $F_{2 \alpha}(p g / m L)$} \\
\hline Çalışma başlangıcı & $59.62(33.45-110.65)$ & 70.68 (45.55-91.15) & & & \\
\hline Çalışma sonu & $63.78(28.3-92.25)$ & $73.21(53.65-103.50)$ & & & \\
\hline Değişim & $4.16(-20.15-27.15)$ & $2.54(-31.95-39.25)$ & 0.575 & 0.779 & 0.916 \\
\hline \multicolumn{6}{|l|}{ CRP (mg/dL) } \\
\hline Çalışma başlangıcı & $0.42(0.32-0.57)$ & $0.38(0.17-0.95)$ & & & \\
\hline Çalışma sonu & $0.38(0.18-0.67)$ & $0.55(0.13-2.15)$ & & & \\
\hline Değişim & $-0.03(-0.35-0.14)$ & $0.17(-0.06-1.20)$ & 0.588 & 0.237 & 0.427 \\
\hline \multicolumn{6}{|c|}{$\begin{array}{l}\text { PSta: Bitkisel stanol esteri içeren yoğurdu tüketen grup, Kntr: Kontrol grubu, TAC } \\
\text { C-reaktif protein } \\
\text { p1, PSta grubu için çalışma başlangıcı ve çalışma sonu Wilcoxon testi sonuçları } \\
\text { p2, Kntr grubu için çalışma başlangıcı ve çalışma sonu Wilcoxon testi sonuçları } \\
\text { p3, PSta ve Kntr gruplarının değişimlerin Mann-Whitney U testi sonuçları }\end{array}$} \\
\hline
\end{tabular}

\section{TARTIŞMA}

Araştırmanın en önemli sonucu, hafif-orta düzey hiperlipidemi tanısı almış bireylerin, $1.9 \mathrm{~g} / \mathrm{gün}$ bitkisel stanol esteri içeren yoğurt tüketimlerinin, beslenme ve yaşam tarzlarından değişiklik yapmadan, önemli düzeyde total kolesterol ve LDL kolesterol düzeylerini azalttığıdır. Öte yandan gerek total antioksidan kapasite gerekse oksidatif stres göstergelerinde istatistiksel açıdan önemli değişiklikler olmamıştır.

Bitkisel sterol ve stanollerin serum antioksidan kapasite üzerinde yaptığı etkiler hala tartışma konusudur. Bu tartışmanın ana konusu, bitkisel sterol ve stanollerin özellikle diyetle alınan yağda çözünen vitaminler ve karotenoidler gibi antioksidan aktivitesi yüksek, eksikliğinde kanser, kardiyovasküler hastalıklar ve makular dejenerasyon gibi çeşitli kronik hastalıklara neden olduğu prospektif çalışmalarca gösterilmiş olan besin ögelerinin emilimini azaltarak, yukarıda bahsedilen durumlara neden olabileceği bilgisidir (12,17-19). Bu bilginin doğruluğu Katan ve arkadaşları (20) tarafından 2003 yılında yayımlanan ve 18 araştırmanın sonuçları ile yaptıkları meta analizde araştırılmıştır. Bu meta analizde, değerlendirmeye günde $1.5 \mathrm{~g}$ ve üzeri dozlarda fitosterol tüketilmiş çalışmalar alınmış ve ham sonuç olarak $\beta$-karoten, $\alpha$-karoten, likopen ve a-tokoferolün serum düzeylerinde sirası ile $\% 19.9$, \%8.7, \%7.3 ve \%5.9'lük azalma gerçekleştiği saptanmıştır. Bu düşüşe serum total kolesterol düzeyindeki azalma düzeltme olarak eklendiğinde ise sırası ile $\% 12.1, \% 0.3, \% 0.1$ ve 
\%2.1 olarak gerçekleşmiştir. Katan ve arkadaşlarının (20) çalışmasında özellikle $\beta$-karotendeki düşüşün diyete eklenecek $\beta$-karoten kaynakları ile telafi edilmesi önerilmektedir. Öte yandan 2017 yllında yayımlanan ve 41 araştırmanın sonuçları ile yapılan başka bir meta analizde, tüketilen bitkisel sterol veya stanol düzeyi ortalama 2.5 g/gün olarak belirlenmiş ve dozun artışına bağlı olarak gerek ham veri ile gerekse serum total kolesterol düzeltmesi yapılmış serum karotenoid düzeyindeki düşüşün daha yüksek olduğu belirlenmiştir (12). Serum karatenoid düzeylerindeki azalmaların sonuçları, çalışmalara total antioksidan kapasitede değişim gerçekleşmemesi olarak yansımıştır. Banus ve arkadaşları (21) 3 ay boyunca sağlıklı bir diyete ek olarak 2 g/gün bitkisel sterol içeren düşük yağlı süt tüketiminin, serum total antioksidan kapasitede bir değişiklik yapmadan total ve LDL kolesterolü istatistiksel olarak önemli düzeyde düşürdüğünü saptamıştır. Buna benzer olarak metabolik sendromlu hastalarda $4 \mathrm{~g} /$ gün bitkisel sterol içeren yoğurdun 2 ay süre ile tüketiminin serum total antioksidan kapasiteyi değiştirmediği belirlenmiştir (22). Mevcut çalışmada da PSta grubundaki kişilerin total antioksidan kapasitelerinde bir değişiklik olmadığı bulunmuştur. Öte yandan bitkisel sterol veya stanol içeren ürünlere yağda eriyen ikincil bir antioksidanın eklenmesinin serum total antioksidan kapasitesinin geliştirilmesine yardımcı olabileceği hayvan çalışmaları ile gösterilmiştir. Sıçanlar üzerinde yapılan böyle bir çalışmada, bitkisel sterol ile zenginleştirilmiş keten tohumu yağına ek olarak E vitamini eklenmesinin antioksidan durumu hafif düzeyde geliştirdiği rapor edilmiştir (23).

Okside LDL (oxLDL), LDL kolesterolün oksidatif stres sonucu oksitlenmesi ile oluşan ve başta monosit ve makrofajlar olmak üzere genel oksidatif stresi arttıran ve koroner arter hastalık gelişiminin de önemli bir göstergesi olarak kabul edilen bir oksidandır (24). Serum LDL kolesterol düzeyindeki azalmanın LDL oksidasyonunu ve buna bağlı olarak oxLDL oluşumunu da azaltacağı ön görülmektedir. Bertalomi ve arkadaşları (25) kolesterol emilimini azaltıcı bir çeşit ilaç olan ezetimibe ile $2.1 \mathrm{~g}$ bitkisel sterol esteri içeren çikolatanın oksidatif stres göstergeleri üzerindeki etkilerini araştırdığı çalışmalarında, hem ezetimibe hem de bitkisel sterol esterlerinin oxLDL oluşumunu sırası ile \%21.1 ve \%20.0 düzeyinde azalttığını belirlemiştir. Buna benzer olarak Sola ve arkadaşları (26), kakao, fındık, çözünür lif ve bitkisel sterol içeren bir ürünün de oxLDL oluşumunu \%6.0 civarında azalttığını belirlemiştir. Mevcut çalışmada da literatürle uyumlu olarak, bitkisel stanol esteri içeren yoğurt tüketen bireylerin oxLDL düzeyinde \%14.8 azalma gerçekleşmiştir. Öte yandan kontrol grubunun da oxLDL düzeylerinde azalma olmuştur.

8-prostaglandin $F_{2 a}$ dokudaki fosfolipitlerin oksijen radikalleri ile oksidasyonu sonucu oluşan ve oksidatif stresin bir göstergesi olan bir eikosanoiddir. Serum 8 prostaglandin $\mathrm{F}_{2 a}$ düzeyinin sigara kullanımına bağlı olarak değiştiği bilinmektedir (27). Bitkisel sterol ve stanollerin alımı ile 8-prostaglandin $\mathrm{F}_{2 a}$ düzeyindeki değişimlerin karşılaştırıldığı çalışma sayısı oldukça azdır. Mannarino ve arkadaşları (28), hafif orta düzeyde hiperkolesterolemi tanılı bireylerde, bitkisel sterol alımının serum yağları ve oksidatif stres göstergeleri üzerindeki etkilerini karşılaştırdığı çalışmasının sonucunda, 6 hafta süresince günde $1.6 \mathrm{~g}$ bitkisel sterol içeren süt ürünü tüketiminin serum total kolesterol ve LDL kolesterol düzeylerinde istatistiksel olarak önemli düzeyde azalmalar gerçekleşmesine karşılık 8-prostaglandin $\mathrm{F}_{2 \alpha}$ düzeyinin değişmediğini belirlemiştir. $\mathrm{Bu}$ çalışmada bitkisel sterol tüketen kişilerin 8-prostaglandin $\mathrm{F}_{2 a}$ düzeylerinde çok az bir azalma gerçekleşmiş olsa da bunun istatistiksel bir önemi bulunmamıştır. Mevcut çalışmada da gerek PSta grubundaki bireylerin gerekse Kntr grubundaki bireylerin serum 8-prostaglandin $\mathrm{F}_{2 a}$ düzeylerinde çok az bir artış gerçekleşmiş olsa da bunun istatistiksel bir anlamı bulunmamıştır.

Birçok çalışmada kardiyovasküler hastalık ile pozitif korelasyonu olan CRP, vücuttaki inflamasyonun en genel göstergelerinden birisidir. Bitkisel sterol/stanol alımının serum CRP düzeyini düşürdüğü çok sayıda çalışmada gösterilmiştir. Devaraj ve arkadaşları (29) günde ikişer defa $1 \mathrm{~g}$ bitkisel sterol içeren düşük enerjili portakal suyu tüketiminin serum CRP 
düzeyini \%12.0 oranında düşürdüğünü göstermiştir. Micallef ve arkadaşları (30), ise günde $2 \mathrm{~g}$ bitkisel sterolü balık yağı ile birlikte tüketmenin serum CRP düzeyini \%39.0 azalttığını belirlemiştir. Öte yandan fitosterol alımının serum CRP düzeyleri üzerindeki etkisini inceleyen, 20 randomize kontrollü çalışmanın bir meta-analiz ise bitkisel sterol veya stanol alımının serum CRP düzeyinin değiştirmediği belirlenmiştir (31). $\mathrm{Bu}$ araştırmada ise bitkisel stanol esteri içeren yoğurt tüketen bireylerin serum CRP düzeyinde istatistiksel olarak anlamlı olmasa da bir azalma olduğu (\%9.5), öte yandan kontrol ürününü tüketen kişilerde ise herhangi bir azalmanın olmadığı, aksine serum CRP düzeyinin istatistiksel olarak anlamlı olmasa da arttığı görülmektedir.

Sonuç olarak bu çalışma ile hafif-orta düzeyde hiperkolesterolemisi olan kişilerin 4 hafta süresince düzenli bitkisel stanol tüketmelerinin serum total ve LDL kolesterol düzeylerini azalttığı, ancak bu azalmanin serum antioksidan kapasite ve oksidatif stres göstergeleri üzerine istatistiksel açıdan önemli bir etkisinin olmadığı saptanmıştır. Öte yandan bunun altında yatan nedenlerin belirlenebilmesi için, daha büyük örneklemle ve daha fazla göstergenin incelendiği, metabolik süreçleri gösterecek randomize kontrollü çalışmalara gereksinme vardır.

Çıkar çatışması - Conflict of interest: Yazarlar çıkar çatışması olmadığını beyan ederler. - The authors declare that they have no conflict of interest.

\section{KAYNAKLAR}

1. Catapano AL, Graham I, De Backer G, Wiklund O, Chapman MJ, Drexel H, et al. 2016 ESC/EAS Guidelines for the Management of Dyslipidaemias: The Task Force for the Management of Dyslipidaemias of the European Society of Cardiology (ESC) and European Atherosclerosis Society (EAS) Developed with the special contribution of the European Assocciation for Cardiovascular Prevention \& Rehabilitation (EACPR). Atherosclerosis 2016;253:281-344.

2. Expert Panel on Detection E, Treatment of High Blood Cholesterol in A, Executive Summary of The Third Report of The National Cholesterol Education Program (NCEP) Expert Panel on Detection, Evaluation, And Treatment of High Blood Cholesterol In Adults (Adult
Treatment Panel III). JAMA 2001;285(19):2486-97.

3. Gylling H, Plat J, Turley S, Ginsberg HN, Ellegard L, Jessup W, et al. Plant sterols and plant stanols in the management of dyslipidaemia and prevention of cardiovascular disease. Atherosclerosis 2014;232(2):34660.

4. Calpe-Berdiel L, Escola-Gil JC, Blanco-Vaca F. New insights into the molecular actions of plant sterols and stanols in cholesterol metabolism. Atherosclerosis 2009;203(1):18-31.

5. Chan YM, Varady KA, Lin Y, Trautwein E, Mensink RP, Plat J, et al. Plasma concentrations of plant sterols: physiology and relationship with coronary heart disease. Nutr Rev 2006;64(9):385-402.

6. De Smet E, Mensink RP, Plat J. Effects of plant sterols and stanols on intestinal cholesterol metabolism: suggested mechanisms from past to present. Mol Nutr Food Res 2012;56(7):1058-72.

7. Stocker R, Keaney JF. Role of oxidative modifications in atherosclerosis. Physiol Rev 2004;84(4):1381-478.

8. Pearson TA, Mensah GA, Alexander RW, Anderson JL, Cannon RO, 3rd, Criqui M, et al. Markers of inflammation and cardiovascular disease: application to clinical and public health practice: A statement for healthcare professionals from the Centers for Disease Control and Prevention and the American Heart Association. Circulation 2003;107(3):499-511.

9. Buyuktuncer Z, Fisunoglu M, Guven GS, Unal S, Besler HT. The cholesterol lowering efficacy of plant stanol ester yoghurt in a Turkish population: a double-blind, placebo-controlled trial. Lipids Health Dis 2013;12:91.

10. Zern TL, Fernandez ML. Cardioprotective effects of dietary polyphenols. J Nutr 2005;135(10):2291-4.

11. Gylling H, Hallikainen M, Nissinen MJ, Miettinen TA. The effect of a very high daily plant stanol ester intake on serum lipids, carotenoids, and fat-soluble vitamins. Clin Nutr 2010;29(1):112-8.

12. Baumgartner S, Ras RT, Trautwein EA, Mensink RP, Plat J. Plasma fat-soluble vitamin and carotenoid concentrations after plant sterol and plant stanol consumption: a meta-analysis of randomized controlled trials. Eur J Nutr 2017;56(3):909-23.

13. De Jong A, Plat J, Bast A, Godschalk RW, Basu S, Mensink RP. Effects of plant sterol and stanol ester consumption on lipid metabolism, antioxidant status and markers of oxidative stress, endothelial function and low-grade inflammation in patients on current statin treatment. Eur J Clin Nutr 2008;62(2):263-73.

14. Franzoni F, Quinones-Galvan A, Regoli F, Ferrannini E, Galetta F. A comparative study of the in vitro antioxidant activity of statins. Int J Cardiol 2003;90(2-3):317-21.

15. Murrow JR, Sher S, Ali S, Uphoff I, Patel R, Porkert M, 
et al. The differential effect of statins on oxidative stress and endothelial function: atorvastatin versus pravastatin. J Clin Lipidol 2012;6(1):42-9.

16. Yilmaz MI, Baykal Y, Kilic M, Sonmez A, Bulucu F, Aydin A, et al. Effects of statins on oxidative stress. Biol Trace Elem Res 2004;98(2):119-27.

17. Bakker MF, Peeters PH, Klaasen VM, Bueno-de-Mesquita HB, Jansen EH, Ros MM, et al. Plasma carotenoids, vitamin C, tocopherols, and retinol and the risk of breast cancer in the European Prospective Investigation into Cancer and Nutrition cohort. Am J Clin Nutr 2016;103(2):454-64.

18. Morris DL, Kritchevsky SB, Davis CE. Serum carotenoids and coronary heart disease. The Lipid Research Clinics Coronary Primary Prevention Trial and Follow-up Study. JAMA 1994;272(18):1439-41.

19. Wu J, Cho E, Willett WC, Sastry SM, Schaumberg DA. Intakes of lutein, zeaxanthin, and other carotenoids and age-related macular degeneration during 2 decades of prospective follow-up. JAMA Ophthalmol 2015;133(12):1415-24.

20. Katan MB, Grundy SM, Jones P, Law M, Miettinen T, Paoletti R, et al. Efficacy and safety of plant stanols and sterols in the management of blood cholesterol levels. Mayo Clin Proc 2003;78(8):965-78.

21. Banuls C, Martinez-Triguero ML, Lopez-Ruiz A, Morillas C, Lacomba R, Victor VM, et al. Evaluation of cardiovascular risk and oxidative stress parameters in hypercholesterolemic subjects on a standard healthy diet including low-fat milk enriched with plant sterols. J Nutr Biochem 2010;21(9):881-6.

22. Sialvera TE, Koutelidakis AE, Richter DJ, Yfanti G, Kapsokefalou M, Micha R, et al. Phytosterol supplementation does not affect plasma antioxidant capacity in patients with metabolic syndrome. Int J Food Sci Nutr 2013;64(1):21-7.

23. Deng Q, Yu X, Xu J, Liu C, Huang F, Huang Q, et al. Effect of flaxseed oil fortified with vitamin $\mathrm{E}$ and phytosterols on antioxidant defense capacities and lipids profile in rats. J Food Sci 2012;77(6):135-40.

24. Levitan I, Volkov S, Subbaiah PV. Oxidized LDL: Diversity, patterns of recognition, and pathophysiology. Antioxid Redox Sign 2010;13(1):39-75.

25. Bertolami A, Botelho PB, Macedo LF, Abdalla DS, Faludi AA, Galasso M, et al. Effect of plant sterols compared with ezetimibe on oxidative stress in patients treated with statins. J Funct Foods 2014;10:178-86.

26. Sola R, Valls RM, Godas G, Perez-Busquets G, Ribalta J, Girona J, et al. Cocoa, hazelnuts, sterols and soluble fiber cream reduces lipids and inflammation biomarkers in hypertensive patients: a randomized controlled trial. PLoS One 2012;7(2):e31103.

27. Dietrich M, Block G, Hudes M, Morrow JD, Norkus EP, Traber MG, et al. Antioxidant supplementation decreases lipid peroxidation biomarker F2-isoprostanes in plasma of smokers. Cancer Epidemiology and Prevention Biomarkers 2002;11(1):7-13.

28. Mannarino E, Pirro M, Cortese C, Lupattelli G, Siepi D, Mezzetti A, et al. Effects of a phytosterol-enriched dairy product on lipids, sterols and 8-isoprostane in hypercholesterolemic patients: a multicenter Italian study. Nutr Metab Cardiovasc Dis 2009;19(2):84-90.

29. Devaraj S, Autret BC, Jialal I. Reduced-calorie orange juice beverage with plant sterols lowers C-reactive protein concentrations and improves the lipid profile in human volunteers. Am J Clin Nutr 2006;84(4):756-61.

30. Micallef MA, Garg ML. Anti-inflammatory and cardioprotective effects of n-3 polyunsaturated fatty acids and plant sterols in hyperlipidemic individuals. Atherosclerosis 2009;204(2):476-82.

31. Rocha VZ, Ras RT, Gagliardi AC, Mangili LC, Trautwein EA, Santos RD. Effects of phytosterols on markers of inflammation: A systematic review and meta-analysis. Atherosclerosis 2016;248:76-83. 